\title{
Pharmacy Practice suffered a plagiarism case
}

\author{
Fernando FERNANDEZ-LLIMOS \\ Editor-in-chief, Pharmacy Practice (Internet).
}

We regret to inform the readers that Pharmacy Practice suffered from a plagiarism case. After an author's complaint, our internal investigation concluded that the article authored by Radhakrishnan RAJESH, Sudha VIDYASAGAR, Krishnadas NANDAKUMAR, entitled "Highly active antiretroviral therapy induced adverse drug reactions in Indian human immunodeficiency virus positive patients", and published on Pharm Pract (Internet) 2011;9(1):48-55 (deliberately not included in this editorial's references), plagiarized a complainant's article.

Following the Committee of Publication Ethics plagiarism flowchart ${ }^{2}$, we contacted the authors' institution, the Principal of Manipal College of Pharmaceutical Sciences, communicating our concern. Few days later, we received a satisfactory resolution from the institution's Scientific Misconduct Enquiry Committee. Additionally, offended author and editors-in-chief of the original publication journal and editors-in-chief of peer journals were also informed.

"There is nothing more debilitating in a journal editor's life than to be involved in a discussion of a case of scientific misconduct". ${ }^{3}$ The "publish or perish" threat was summarized long time ago by the statement: "In order to receive grants or promotions it is necessary for them [researchers] to keep their names in print over articles". ${ }^{4}$ Unethical shortcuts exist, and unfortunately, journal editors have to act as cops.

After this first case of publication fraud identified in Pharmacy Practice, we establish a procedure to check all manuscripts for potential plagiarism prior to the external peer-review process. Through this investigative process we have learnt a lot. However, we also identified some pitfalls in the plagiarism concept.

Plagiarism is a concept without a clear definition. Plagiarism is "the presentation of another person's words, work, or ideas as one's own". However, "how much textual similarity raises the suspicion of plagiarism?" Something seems to be clear: the plagiarism offender treacherously steals the work of the offended author. From this point of view, using the term 'self-plagiarism' may be unhelpful. This term is not only an oxymoron $^{7}$, but also may conceal the burden of the real plagiarism fraud. Authors cannot steal their own intellectual property. They may fall into a different publication fraud named as 'redundant publication' by the International Committee of Medical Journal Editors. ${ }^{8}$

Plagiarism seems to be a very common issue in academic publishing, and it produces an important number of journal pages. To date, more than 740 articles are indexed in Pubmed using 'plagiarism' as Medical Subject Heading, and more than 400 use the word plagiarism in their titles. Even top leading journals recognized suffering from plagiarism cases.

To reduce the plagiarism and avoid its generalization different solutions have been suggested. Identifying plagiarism is a difficult task. Some text-similarity search engines were developed, demonstrating good results on plagiarism identification. These tools use abstracts indexed in Pubmed to check for similar publications. Two concerns should be taken into account: are we creating a new generation of plagiarism offenders with expertise on getting past these engines? ${ }^{9}$ And, second, what about journals not indexed in Pubmed? Unethical authors may plagiarize articles from those journals, and they will never be identified. This is another reason for the need of the International Catalogue of Scientific literature. ${ }^{10}$

Obviously, the first action after identifying any publication fraud consists on retracting the article. Retracting does not mean deleting, but flagging the article in databases and webpages as retracted. This could be a simple task if only one database existed and the article was available through one webpage only. The lack of effectiveness of this process is evident, since retracted articles are being cited even after the retraction. ${ }^{11}$ This is even more difficult for open access journals, with an open self-archiving policy. How many library databases and secondary sources and how many repositories have recorded the article since it was published until the retraction is effective?

And finally, what to do with dishonest authors after a plagiarism case? It seems that plagiarism offenders tend to repeat the fraud. " ${ }^{12}$ "Scientific fraud, in its many manifestations, is no different from any other form of fraud and should be dealt with as such with appropriate penalties" ${ }^{13}$ The Committee of Publication Ethics plagiarism flowchart does not provide other action than "inform": inform victims, inform readers, inform offender institution. And, what else? Conversely, some countries have established strict policies and penalties for dishonest authors. ${ }^{14}$

Not only plagiarism, but all types of scientific misconduct constitute a frequent and serious problem that we all should be aware of and address together. 


\section{References}

1. Modayil RR, Harugeri A, Parthasarathi G, Ramesh M, Prasad R, Naik V, Giriyapura V. Adverse drug reactions to antiretroviral therapy (ART): an experience of spontaneous reporting and intensive monitoring from ART centre in India. Pharmacoepidemiol Drug Saf. 2010;19(3):247-55.

2. Committee of Publication Ethics. What to do if you suspect plagiarism. b) Suspected plagiarism in a published article. URL: http://publicationethics.org/files/u2/02B_Plagiarism_Published.pdf (accessed 29-Feb-2012)

3. Balaran P. Probing misconduct: treading a dangerous path. Curr Sci 2007;92(11):1467-1468.

4. Brandon AN. "Publish or perish". Bull Med Libr Assoc. 1963;51:109-110.

5. Anderson MS, Steneck NH. The problem of plagiarism. Urol Oncol. 2011;29(1):90-94.

6. Bazdaric K. Plagiarism detection - quality management tool for all scientific journals. Croat Med J. 2012;53(1):1-3.

7. Chrousos GP, Kalantaridou SN, Margioris AN, Gravanis A. The 'self-plagiarism' oxymoron: can one steal from oneself? Eur J Clin Invest. 2012;42(3):231-232.

8. ICMJE. Overlapping Publications. URL: http://www.icmje.org/publishing_4overlap.html (accessed 29-Feb-2012)

9. Anderson M. Catch system gamers. Nature 2012;481(7379):23.

10. Adler C. The international catalogue of scientific literature. Science. 1897;6(136):184-201.

11. Garner H. Flag plagiarized studies. Nature 2012;481(7379):21.

12. Zhang $Y$, McIntosh I. Blacklist repeat offenders. Nature 2012;481(7379):22.

13. Triggle CR, Triggle DJ. What is the future of peer review? Why is there fraud in science? Is plagiarism out of control? Why do scientists do bad things? Is it all a case of: "all that is necessary for the triumph of evil is that good men do nothing"? Vasc Health Risk Manag. 2007;3(1):39-53.

14. Nylenna M, Andersen D, Dahlquist G, Sarvas M, Aakvaag A. Handling of scientific dishonesty in the Nordic countries. National Committees on Scientific Dishonesty in the Nordic Countries. Lancet. 1999;354(9172):57-61. 